\title{
O.DIALEKTIKA
}

ISSN: $2338-2635$

\section{MASALAH YANG DIHADAPI PELAJAR BAHASA INGGRIS DALAM MEMAHAMI PELAJARAN BAHASA INGGRIS}

\author{
Gunawan Tambunsaribu ${ }^{1}$, Yusniaty Galingging ${ }^{2}$, \\ ${ }^{1,2}$ Program Studi Sastra Inggris, Fakultas Sastra dan Bahasa, Universitas Kristen Indonesia \\ gunawanreza tamsar@yahoo.com*, galinggingyusniaty@gmail.com
}

\begin{abstract}
Abstrak
Dalam proses mempelajari bahasa Inggris sebagai bahasa asing di Indonesia sampai sekarang masih tetap menjadi momok bagi sebagian besar pelajar di Indonesia. Penelitan ini bertujuan untuk mengetahui kesulitan-kesulitan para pelajar dalam proses pembelajaran bahasa Inggris. Diharapkan bahwa hasil penelitian ini berguna bagi para pengajar bahasa Inggris untuk menemukan solusi untuk menangani kesulitan-kesulitan yang dialami para pelajar bahasa Inggris. Ada tiga (3) jenis masalah dalam penelitian ini, yaitu 1) Materi pelajaran manakah yang menjadi kesulitan utama para mahasiswa selama proses pembelajaran bahasa Inggris semenjak mereka belajar belajar bahasa Inggris?; 2) Faktor apa sajakah yang menyebabkan mahasiswa merasa sulit dalam mempelajari bahasa Inggris sampai saat ini?; dan 3) Adakah pengalaman buruk yang mereka dapatkan dari pengajar bahasa Inggris sehingga mereka mengalami kesulitan dalam memahami pelajaran bahasa Inggris? Metode yang dipakai oleh peneliti dalam penelitian ini adalah metode kualitatif dengan pendekatan deskriptif. Data primer dalam penelitian ini adalah 400 responden yang mengisi kuesioner dan juga memberikan pernyataan pada proses interview. Hasil dari penelitian ini menginformasikan bahwa materi pelajaran bahasa Inggris yang sulit dipelajari oleh mahasiswa mulai dari tingkat paling sulit diantaranya; Grammar (66\%), Speaking (22\%), Listening (7\%), Writing (4\%), dan Reading (1\%). Para responden memberitahukan bahwa sangat besar pengaruh guru atau pengajar terhadap kemampuan mereka dalam menguasai belajar Bahasa Inggris. Penulis mengelompokkan masalah yang mereka hadapi dari guru/pengajar ke dalam 3 kategori umum, yaitu, 1) Guru bersikap tidak menyenangkan; 2) Metode pengajaran guru kurang interaktif atau pasif; dan 3) Guru tidak ahli mengajar pelajaran bahasa Inggris. Penulis mengelompokkan faktor internal penyebab masalah ke dalam tiga kategori umum, yaitu a) Mereka menganggap bahasa Inggris itu membingungkan (77\%); b) Mereka tidak suka pelajaran bahasa Inggris (15\%); dan c) Mereka mengatakan bahwa bahasa Inggris itu tidak penting (8\%).
\end{abstract}

Kata Kunci: Kesulitan belajar bahasa Inggris, Permasalahan belajar bahasa Inggris, faktor eksternal dan internal

\begin{abstract}
Learning English as a foreign language still becomes a burden for most students in Indonesia. The main goal of this research is to find out some of the main problems Indonesian students face in learning English. There are three problems in this research, namely: 1) what topic is the most difficult for the students to understand since they learned English for the first time until now? 2) What are the factors which cause them difficulty to understand English topics until now? and 3) was there any bad experience they had in learning English that made them difficult to understand English topics? The researcher used the qualitative descriptive method in conducting this research. The primary data are from the questionnaires and the interview results from the respondents. There are 400 respondents, college students, who participated in this research. The analysis includes graphs related to data taken from the questioners and a brief
\end{abstract}


explanation based on the interview session. This researcher found out that the English topics that are still difficult to understand by the students are as follows; Grammar (66\%), Speaking (22\%), Listening (7\%), Writing (4\%), and Reading (1\%). The researcher classifies all the problems faced by the respondents in learning English into three general problems are: 1) The teacher had an uncomfortable attitude; 2) The teaching methods from the English teacher is passive; 3) the English teacher does not have enough knowledge in English. The researcher also classified the internal factors that make the students difficult to learn English into three main categories. They are; 1) the students think that the English lesson is confusing (77\%); 2) They do not like English (15\%); 3) They said English skill is not important to them (8\%). It is hoped that this research results can be helpful for English teachers as a piece of important information related to their students' problems and the factors that make them difficult to learn and understand English. It can also reflect that English teachers generally related to their skills and methods in teaching English.

Keywords: Problems in Learning English, English Topics; Internal and External factors

\section{Pendahuluan}

Pengalaman peneliti dalam mengajar pelajaran bahasa Inggris kepada siswa dan mahasiswa membuat penulis ingin mengetahui lebih dalam mengenai permasalahan yang dihadapi para pelajar/mahasiswa alami dalam belajar bahasa Inggris. Peneliti merasa penasaran untuk mengetahui alasan masih banyak mahasiswa yang masih mendapatkan kesulitan memahami mata kuliah bahasa Inggris meskipun mereka sudah mengenal dan belajar bahasa Inggris sejak mereka di TK (Taman Kanak-kanak) dan SD (Sekolah Dasar). Untuk menjawab rasa penasaran ini, peneliti ingin melakukan penelitian lebih mendalam mengenai kesulitan-kesulitan dan sumber kesulitan yang dihadapi para mahasiswa tersebut.

\subsection{Latar Belakang Penelitian}

Dalam proses mempelajari bahasa Inggris sebagai bahasa asing di Indonesia sampai sekarang masih tetap menjadi momok buat sebagian pelajar di Indonesia. Sebagian besar menganggap bahasa Inggris itu sulit. Anggapan bahwa pelajaran bahasa Inggris itu sulit menjadikan sebagian pelajar merasa enggan meningkatkan kemampuan bahasa Inggris mereka.

Proses belajar-mengajar di dunia pendidikan memang tidak selamanya mengalami kelancaran apalagi bagi mereka yang memang tidak menyukai beberapa mata pelajaran yang harus mereka pelajari. Selalu saja ada hambatan dalam proses belajar mengajar di tempat pendidikan manapun. Kesulitan belajar tersebut akan berdampak pula pada penurunan prestasi akademik peserta didik yang sedang mengemban pendidikan tersebut. Oleh karena itu, sebagain besar para pendidik merasa bertanggung jawab untuk terus melakukan penelitian yang diantaranya ada yang menganalisa kesulitan yang 
dialami pelajar; ada yang meneliti tentang factor eksternal dan internal penyebab kesulitan belajar pelajar; ada yang mengembangkan metode pembelajaran agar pelajar merasa tertarik belajar; dan penelitian-penelitian lainnya yang bertujuan untuk mengembangkan dan meningkatkan ilmu dan juga memajukan proses belajar mengajar di kelas.

Para pengajar sebagai pendidik tentunya merasa bertanggung jawab atas perkembangan para peserta didik. Karena itu para pendidik dalam proses pengajaran semestinya memperhatikan kemampuan peserta didik secara individual dengan tujuan mengetahui dan membantu perkembangan peserta didik secara optimal. Dengan mengetahui kelebihan dan kekurangan para peserta didik, para pendidik dapat melakukan pengembangan metode pembelajaran dan penelitian dalam kelas.

Pengajar harus memahami faktor-faktor yang mempengaruhi proses dan hasil belajar para peserta didik karena kesulitan belajar bersumber pada faktor-faktor tersebut. Penelitan yang bertujuan untuk mengetahui kesulitan-kesulitan para pelajar dalam proses pembelajaran akan sangat berguna bagi para pengajar lainnya untuk menemukan solusi dalam menangani kesulitan-kesulitan yang dialami para pelajar tersebut.

Hal inilah yang mendasari diperlukannya sebuah konsep diagnostik kesulitan belajar yang dialami para mahasiswa khususnya dalam hal ini pembelajaran bahasa Inggris yang sudah bertahun-tahun mereka pelajari sejak sekolah dasar sampai tingkat perkuliahan.

\subsection{Masalah Penelitian}

Ada dua (3) jenis masalah dalam penelitian ini, yaitu:

1. Materi pelajaran manakah yang menjadi kesulitan utama para mahasiswa selama proses pembelajaran bahasa Inggris semenjak mereka belajar belajar bahasa Inggris.

2) Faktor apa sajakah yang menyebabkan mahasiswa merasa sulit dalam mempelajari bahasa Inggris sampai saat ini?

\section{Kerangka Teori}

\subsection{Konsep Diagnostik Kesulitan Belajar}

Dalam proses belajar mengajar di dalam kelas, para pengajar tentunya tidak hanya fokus dalam memberikan materi kepada para pelajar tetapi mereka juga dituntut untuk bertanggung jawab atas perkembangan para pelajar. Menemukan dan memahami kesulitan belajar para pelajar dikenal dengan konsep diagnostik kesulitan belajar. Menurut Harriman (1980) dalam bukunya Handbook of Psychological Term, diagnosis 
adalah suatu analisis terhadap kelainan atau salah penyesuaian dari pola gejalagejalanya. Jadi diagnosis merupakan proses pemeriksaan terhadap hal-hal yang dipandang tidak beres atau bermasalah.

Maka dapat disimpulkan bahwa diagnosis adalah penentuan jenis masalah atau kelainan dengan meneliti latar belakang penyebabnya atau dengan cara menganalisis gejalagejala yang tampak.

Menurut Cece Wijaya (2010) dalam bukunya yang berjudul "Pendidikan Remidial" menyatakan kesulitan-kesulitan pembelajaran itu dikategorikan dalam empat hal, yaitu:

a) Dyslexia, adalah kelemahan-kelemahan belajar di bidang menulis dan berbicara. Ciri cirinya adalah sulit mengingat huruf, kata, tulisan, dan suara.

b) Dyscalculia, adalah kesulitan mengenal angka dan pemahaman terhadap konsep dasar matematika.

c) Attention Defisit Hyperactive Disorder (ADHD), adalah pemusatan perhatian terhadap masalah-masalah yang sedang dihadapinya

d) Spatial, motor, ad perceptual defisits, adalah kondisi lemah dalam menilai dirinya menurutukuran ruang dan waktu. Kerusakan lainnya yang membuat siswa lamban belajar adalah Social defisits, yaitu kesulitan mengembangkan keterampilan sosial.

\subsection{Konsep Bahasa}

Menurut Anderson (dalam Tarigan, 2015:21) bahasa merupakan sebuah sarana komunikasi. Bahasa itu tidak hanya dimengerti si pembicara tetapi juga harus dipahami oleh orang lain sebagai pendengar. Jika pesan pada ujaran atau ucapan si pembicara tidak dapat dipahami oleh si pendengar maka gagallah komunikasi tersebut. Oleh karena itu, bahasa sebagai alat komunikasi sangat penting dalam kehidupan perseorangan maupun kelompok dalam bermasyarakat.

Menurut Anderson (dalam Tarigan, 2015: 19-22) ada delapan prinsip dasar bahasa yang merupakan hakikat bahasa itu sendiri, yaitu: 1) Bahasa adalah suatu system; 2) Bahasa adalah vocal yang berupa ujaran. Ujaran mengandung segala tanda utama suatu bahasa sedangkan huruf-huruf merupakan sarana dan upaya untuk mewakili bunyi-bunyian suatu bahasa; 3) Bahasa tersusun dari lambing-lambang arbitrer; 4) Setiap bahasa bersifat unik dan memiliki ciri khas; 5) Bahasa dibangun dari kebiasaan-kebiasaan; 6) Bahasa adalah sarana komunikasi; 7) Bahasa berhubungan dengan budaya setempat; dan 8) Bahasa itu bersifat dinamis dan dapat berubah.

\subsection{Faktor Kesulitan dalam Belajar}


Irham dan Wiyani (2013:254) menyatakan bahwa kesulitan dalam hal belajar merupakan suatu keadaan saat siswa mengalami hambatan dalam mengikuti proses belajar mengajar sehingga mencapai hasil belajar yang tidak optimal. Menurut Blassic \& Jones (dalam Irham \& Wiyani 2013:253), kesulitan yang dialami siswa dalam belajar menunjukkan adanya kesenjangan antara prestasi akademik yang diharapkan dengan yang dicapai oleh siswa pada aktualnya. Hamalik (1983:112) juga menyatakan bahwa kesulitan siswa dalam belajar merupakan gangguan yang dapat menghambat kemajuan belajar siswa dan juga dapat mengakibatkan kegagalan prestasi siswa.

Menurut Abdurrahman (2003) mengatakan bahwa kesulitan belajar dapat dibagi kedalam dua kelompok besar, yakni:

1. Kesulitan belajar yang berhubungan dengan perkembangan (developmental learning disabilities). Subkategori dari kesulitan ini adalah: a) kesulitan belajar yang berhubungan dengan perkembangan mencakup gangguan motorik dan persepsi, b) kesulitan belajar bahasa dan komunikasi, dan c) kesulitan belajar dalam penyesuaian perilaku sosial.

2. Kesulitan belajar akademik (academic learning disabilities) yaitu kesulitan belajar yang mencakup adanya kegagalan-kegagalan pencapaian prestasi akademik yang sesuai dengan kapasitas yang diharapkan. Kegagalan-kegagalan tersebut mencakup penguasaan keterampilan dalam membaca, menulis, atau matematika.

Sejalan dengan itu, Ahmadi dan Supriyono (2004), menjelaskan faktor-faktor penyebab kesulitan belajar dapat digolongkan kedalam dua golongan yaitu faktor intern dan faktor ekstern.

1) Faktor intern (faktor dari dalam diri manusia itu sendiri) yang meliputi:

a. Faktor fisiologi Faktor fisiologis yang dapat menyebabkan munculnya kesulitan belajar pada siswa seperti kondisi siswa yang sedang sakit, kurang sehat, adanya kelemahan atau cacat tubuh dan sebagainya.

b. Faktor psikologi Faktor psikologi siswa yang dapat menyebabkan kesulitan belajar meliputi tingkat intelegensi pada umumnya rendah, bakat terhadap mata pelajaran rendah, minat belajar yang kurang, motivasi yang rendah, dan kondisi kesehatan mental yang kurang baik.

2) Faktor ekstern (faktor dari luar manusia) meliputi:

a. Faktor-faktor non-sosial. Faktor non-sosial yang dapat menyebabkan kesulitan belajar pada siswa dapat berupa peralatan belajar atau media belajar yang kurang baik atau 
bahkan kurang lengkap, kondisi ruang belajar atau gedung yang kurang layak, kurikulum yang sangat sulit dijabarkan oleh guru dan dikuasai oleh siswa, waktu pelaksanaan proses pembelajaran yang kurang disiplin, dan sebagainya.

b. Faktor-faktor sosial. Faktor-faktor sosial yang juga dapat menyebabkan munculnya permasalahan pada siswa seperti faktor keluarga, faktor sekolah, teman bermain, dan lingkungan masyarakat yang lebih luas. Faktor sosial lainnya yang dapat menyebabkan kesulitan belajar pada siswa adalah faktor guru.

Menurut Ahamadi dan Supriyono (2004), karakterisitik seorang guru yang dapat menyebabkan siswa mengalami kesulitan dalam belajar adalah sebagai berikut: 1) Guru yang kurang kompeten dalam mengampu/mengajar mata pelajaran dan memilih metode pembelajaran yang akan digunakan dalam proses pembelajaran; 2). Guru yang mempunyai pola hubungan yang kurang baik dengan siswa. Sifat guru yang sepert ini biasaya suka marah, otoriter, sombong, tidak pandai menjelaskan materi, pelit dalam memberikan nilai, dan sikap negative lainnya; dan 3) Guru yang menetapkan dan menuntut standar keberhasilan belajar siswa terlalu tinggi diatas kemampuan siswa pada umumnya.

Menurut Irham dan Wiyani (2013:266) mengatakan bahwa ada beberapa factor penyebab siswa mengalami kesulitan dalam belajar disebakan oleh dua factor, yaitu factor internal dan eksternal. Faktor internal meliputi; a) sikap siswa terhadap belajar, b) motivasi belajar siswa, c) konsentrasi belajar siswa, d) cara siswa mengolah bahan ajar, e) kemampuan siswa menyimpan perolehan hasil belajar, f) proses siswa dalam menggali hasil belajar yang tersimpan, g) kemampuan siswa untuk berprestasi dan unjuk bekerja, h) rasa percaya diri siswa, i) intelegansi dan keberhasilan siswa, j) kebiasaan belajar siswa, dan k) cita-cita siswa itu sendiri. Sedangkan faktor eksternal yang ikut mempengaruhi kesulitan siswa dalam hal belajar meliputi: a) guru sebagai pembina siswa, b) sarana dan prasarana pembelajaran, c) kebijakan penilaian, d) lingkungan social siswa di sekolah, dan e) kurikulum sekolah.

Kirk \& Gallagher (1989:197) berpendapat bahwa ada empat faktor yang menyebabkan pelajar sulit dalam hal belajar. Empat hal tersebut adalah:

1. Faktor Kondisi fisik. Faktor kondisi fisik dalam hal ini meliputi gangguan visual, gangguan pendengaran, gangguan keseimbangan dan orientasi ruang, body image yang rendah, hiperaktif, serta kurang gizi. 
2. Faktor Lingkungan. Kesulitan belajar yang disebabkan oleh lingkungan keluarga, masyarakat dan sekolah yang kurang menguntungkan bagi pelajar yang pada akhirnya faktor ini akan menghambat perkembangan kejiwaan, social, juga berimbas pada pencapaian prestasi akademis.

3. Faktor motivasi dan afeksi. Kedua faktor ini dapat juga dapat meningkatkan kesulitan belajar pelajar itu sendiri. Anak yang kurang percaya diri karena sering gagal pada salah satu atau beberapa pelajaran cenderung akan mengalami sikap rendah diri. Sikap rendah diri tentunya sangat mengurangi motivasi belajar pada si anak. Dengan sikap rendah hari akan memunculkan perasaan negative si anak terhadap hal-hal yang berhubungan hal belajar. Pikiran negative tersebut dapat membuat anak menjadi pasif dan enggan belajar.

4. Faktor Kondisi Psikologis. Faktor kondisi psikologis ini mencakup gangguan perhatian, persepsi visual, persepsi pendengaran, persepsi motorik, ketidakmampuan berfikir, dan lambat dalam kemampuan berbahasa.

Setelah mengetahui pendapat beberapa ahli mengenai factor-faktor penyebab siswa mengalami kesulitan dalam hal belajar, dapatlah kita simpulkan bahwa secara umum ada dua factor penyebab pelajar mengalami kesulitan dalam belajar yaitu factor internal dan eksternal. Faktor internal disebabkan dari dalam diri pelajar itu sendiri sedangkan faktor eksternal bersumber dari luar dirinya pelajar tersebut seperti dari lingkungan keluarga, sekolah, masyarakat, dan juga dari lingkungan pertemanan. Dua faktor tersebut menyebabkan pelajar sulit belajar dalam hal ini sulit menerima, memahami dan juga mengaplikasikan ilmu yang diajarkan padanya. Kesulitan tersebut juga akan mengakibatkan pelajar memperoleh prestasi belajar yang rendah dan bahkan dapat tidak lulus dari standar prestasi yang ditetapkan.

\section{Metode Penelitian}

Metode yang dipakai oleh peneliti dalam penelitian ini adalah metode kualitatif dengan pendekatan deskriptif.

\subsection{Instrumen Penelitian}

Alat yang digunakan dalam penelitian ini adalah perekam suara/video dan kertas kuesioner. Sedangkan teknik yang dilakukan peneliti dalam mengumpulkan data penelitian adalah melalui wawancara dan penyebaran kuesioner.

a) Kuesioner 
Untuk mendapatkan data dari para responden, peneliti juga dibantu oleh beberapa mahasiswa yang sedang peneliti ajar di semester 7 (tingkat IV) untuk menyebarkan serta mengumpulkan hasil kuesioner dari para responden.

b) Wawancara

Untuk melakukan wawancara kepada para responden, peneliti juga meminta bantuan beberapa mahasiswa semester 5 (tingkat III), yang sedang peneliti ajar di kampus tersebut, dalam melakukan interview terhadap para responden.

\subsection{Data Penelitian}

Data primer dalam penelitian ini adalah hasil jawaban dari para responden/informan terhadap semua pertanyaan dalam kuesioner dan juga dalam interview yang diberikan kepada mereka. Dari hasil jawaban responden terhadap pertanyaan yang diajukan dalam kuesioner dan interview akan didapatkan jawaban atas masalah-masalah dalam penelitian ini.

\subsection{Responden}

Para mahasiswa tingkat pertama angkatan 2016 di Universitas Gunadarma Bekasi. Peneliti secara acak memilih 400 orang mahasiswa yang pada semester aktif sedang mempelajari mata kuliah bahasa Inggris I.

\section{Hasil Penelitian dan Pembahasan}

Dari masalah penelitian dalam penelitian ini, di bawah ini peneliti akan menjawab serta menjelaskan masalah penelitian. Di bab IV ini peneliti akan menguraikan jawaban yang didapatkan sebagai jawaban dari pertanyaan yang ditanyakan dalam masalah penelitian.

Masalah I: Materi pelajaran manakah yang menjadi kesulitan utama para mahasiswa selama proses pembelajaran bahasa Inggris semenjak mereka belajar belajar bahasa Inggris?

A) Questioner dan Interview pertama: "Di dalam mempelajari bahasa Inggris sampai perkuliahan ini, materi pelajaran apakah yang paling sulit Anda kuasai?”

Dari hasil analisis sebanyak 400 responden terhadap pertanyaan pada kuesioner pertama, ada sembilan (9) materi pelajaran yang mahasiswa sebutkan sebagai materi yang paling sulit bagi mereka yaitu:

1) Grammar (48\%) 
2) Kosa-kata (13\%)

3. Pronunciation $(12 \%)$

4. Speaking $(9 \%)$

5. Translation $(6 \%)$

6. Reading (4\%):

7. Listening $(5 \%)$

8. TOEFL (3\%)

9. Writing (1\%)

B) Questioner dan Interview kedua.

Dari sembilan (9) jawaban materi pelajaran yang paling sulit mahasiwa pahami dalam belajar bahasa Inggris, peneliti ingin mempersempit lagi pilihan para responden dengan membuat kuesioner kedua dengan hanya memberikan pilihan empat (5) nama keterampilan bahasa Inggris.

Pertanyaan pada kuesioner kedua ini adalah sebagai berikut:

Di dalam mempelajari bahasa Inggris sampai di perkuliahan, silahkan Anda pilih salah satu materi yang sangat sulit bagi Anda dalam pelajaran bahasa Inggris. Berikan jawaban Anda dengan memberikan tanda (X) pada pilihan Anda.
a) Grammar
b) Listening
c) Speaking
d) Reading
e) Writing

Setelah semua di dapatkan, semua hasil dianalisis oleh peneliti. Hasil yang didapatkan dapat kita lihat pada grafik di bawah ini.

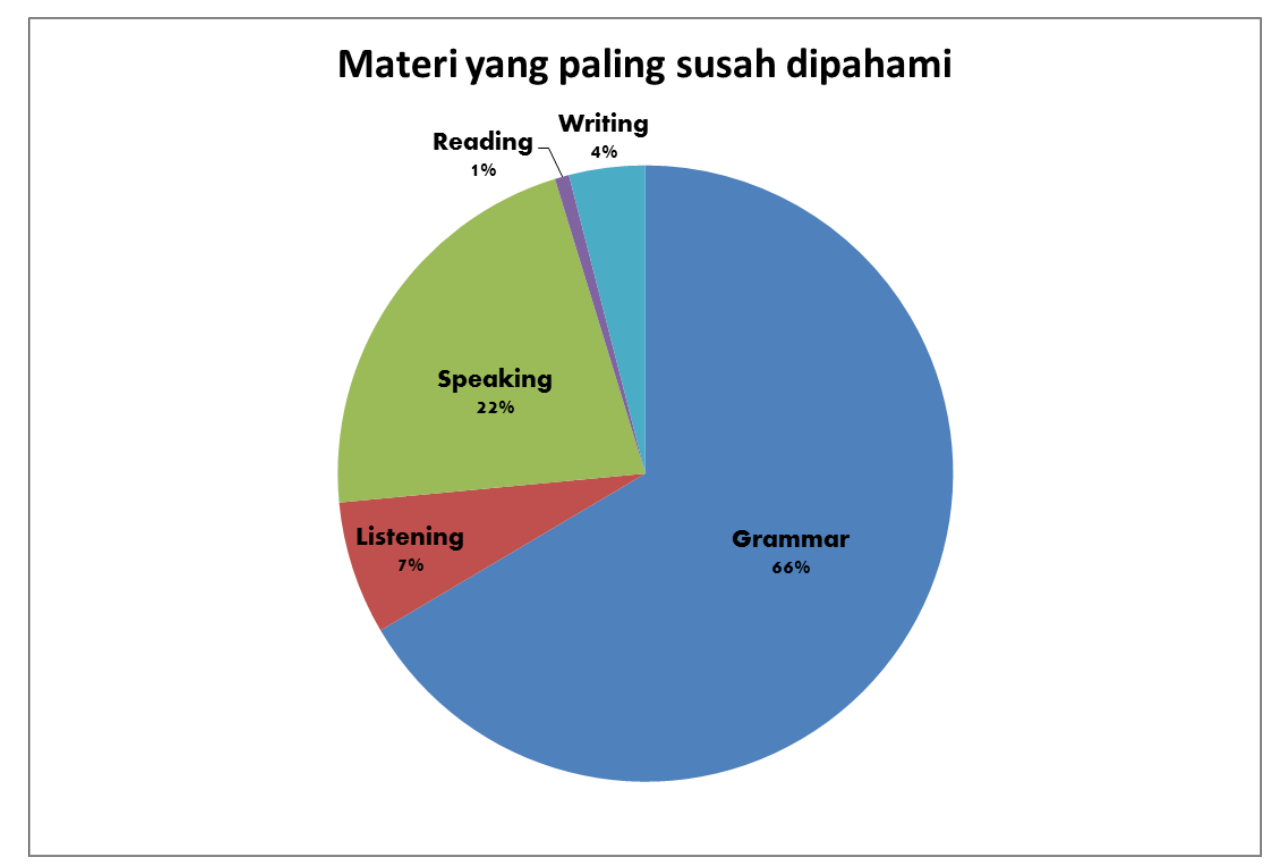


Dari grafik kita dapat melihat bahwa materi pelajaran bahasa Inggris yang sangat sulit dipelajari/dipahami oleh mahasiswa adalah materi grammar/struktur bahasa Inggris. Sebanyak 66\% responden mengatakan materi grammar bahasa Inggris paling membingungkan mereka. Di peringkat kedua tertinggi dalam hal materi yag paling sulit dipejari, sebanyak 22\% mahasiswa mengatakan materi Berbicara (Speaking) adalah yang sangat sulit untuk mereka kuasai. Di peringkat ketiga materi yang paling sulit dipelajari, sebayak 7\% mahasiswa mengatakan sangat sulit dalam pelajaran Mendengarkan (Listening) Diperingkat ke empat, sebanyak 4\% mahasiswa mengatakan bahwa materi Menulis (Writing) paling sulit dipahami. Di peringkat terendah, sebanyak $1 \%$ mahasiswa mengatakan bahwa yang paling sulit untuk mereka pahami adalah materi Membaca (Reading)

Masalah II: Apa saja faktor yang menyebabkan mahasiswa merasa sulit dalam mempelajari bahasa Inggris sampai saat ini?

A. Faktor Pengaruh guru/pengajar (Eksternal).

Dari hasil penelitian ini, para responden memberitahukan bahwa sangat besar pengaruh guru/pengajar terhadap kemampuan mereka dalam menguasai belajar bahasa Inggris. Dari semua masalah yang mereka kemukakan pada saat wawancara, penulis mengelompokkan masalah yang mereka hadapi dari guru/pengajar ke dalam 3 kategori umum, yaitu:

1. Guru bersikap tidak menyenangkan (Strict/uncomfortable teacher)

2. Metode guru kurang interaktif atau pasif (Poor Teaching methods/Pasive teacher)

3. Guru tidak ahli mengajar mata kuliah bahasa Inggris (Incapable/Unskilled teacher)

B. Faktor Pengaruh dari kemauan/inisiatif pelajar (Factor Internal)

Dalam penelitian ini, para siswa mengatakan bahwa masalah yang berasal dari setiap mereka ada beberapa macam hal. Penulis mengelompokan kedalam tiga kategori, yaitu:

1. Mereka menganggap bahwa bahasa Inggris itu membingungkan (English is confusing);

2. Mereka tidak menyukai bahasa Inggris (Dislike English); dan

3. Mereka menganggap bahwa bahasa Inggris itu kurang penting (English is less important)

Faktor internal yang menyebabkan mahasiswa/pelajar mengalami kesulitan dalam memahami bahasa Inggris adalah sebagai berikut: 
a) Mereka menganggap bahasa Inggris itu membingungkan (English is confusing). Sebanyak 77\% mengatakan bahwa bahasa Inggris itu sulit dan membingungkan.

b) Mereka tidak suka pelajaran bahasa Inggris. Sebanyak $15 \%$ dari responden menyatakan bahwa mereka tidak meyukai bahasa Inggris. Hal ini erat hubungannya dengan poin A bahwa bahasa Inggris itu sulit dan membingungkan.

c) Sebanyak $8 \%$ dari responden mengatakan bahwa bahasa Inggris itu tidak penting.

\section{Kesimpulan dan Saran}

\subsection{Kesimpulan}

Dapat kita simpulkan bahwa materi pelajaran bahasa Inggris yang sangat sulit dipelajari/dipahami oleh mahasiswa adalah materi grammar/struktur bahasa Inggris. Sebanyak 66\% responden mengatakan materi grammar bahasa Inggris paling membingungkan mereka. Di peringkat kedua tertinggi dalam hal materi yag paling sulit dipejari, sebanyak 22\% mahasiswa mengatakan materi Berbicara (Speaking) adalah yang sangat sulit untuk mereka kuasai. Di peringkat ketiga materi yang paling sulit dipelajari, sebayak 7\% mahasiswa mengatakan sangat sulit dalam pelajaran Mendengarkan (Listening) Diperingkat ke empat, sebanyak 4\% mahasiswa mengatakan bahwa materi Menulis (Writing) paling sulit dipahami. Di peringkat terendah, sebanyak $1 \%$ mahasiswa mengatakan bahwa yang paling sulit untuk mereka pahami adalah materi Membaca (Reading).

Faktor yang menyebabkan mahasiswa merasa sulit dalam mempelajari bahasa Inggris sampai saat ini adalah factor internal dan eksternal. Para responden memberitahukan bahwa sangat besar pengaruh guru/pengajar terhadap kemampuan mereka dalam menguasai belajar bahasa Inggris. Penulis mengelompokkan masalah yang mereka hadapi dari guru/pengajar ke dalam 3 kategori umum, yaitu, 1) Guru bersikap tidak menyenangkan (Strict/uncomfortable teacher); 2) Metode guru kurang interaktif atau pasif (Poor Teaching methods/Pasive teacher); dan 3) Guru tidak ahli mengajar mata kuliah bahasa Inggris (Incapable/Unskilled teacher).

Para pelajar mengatakan bahwa masalah yang berasal dari dalam diri mereka sendiri. Penulis mengelompokan factor internal ini ke dalam tiga alasan individu, yaitu:

a) Mereka menganggap bahasa Inggris itu membingungkan (77\%).

b) Mereka tidak suka pelajaran bahasa Inggris (15\%).

c) Mereka mengatakan bahwa bahasa Inggris itu tidak penting (8\%).

\subsection{Saran}


Dengan adanya penelitian ini, penulis sangat mengharapkan hasil penelitian ini menjadi panduan bagi para pengajar khususnya pengajar bahasa Inggris di seluruh wilayah Indonesia untuk melakukan penelitian lanjutan khusunya pada materi pelajaran lainnya. Penelitian ini juga sangat diharapan oleh penulis menjadi bahan kajian para peneliti psikologi untuk mendalami pemahaman mengenai factor psikologis para pelajar sehingga masih sulit memahami bahasa Inggris meskipun sudah puluhan tahun belajar bahasa tersebut. Penelitian ini juga sangat membantu para pengajar untuk merefleksi diri kita agar menjadi penyemangat dan pengajar yang benar-benar ingin mengembangkan dan meningkatkan kemampuan berbahasa Inggris pelajar.

\section{Daftar Pustaka}

Abdurrahman, Mulyono. 2003. Pendidikan Bagi Anak Berkesulitan Belajar. Jakarta: Rineka Cipta

Abu Ahmadi \& Supriyono Widodo. (2004). Psikologi Belajar. Jakarta: PT Rineka Cipta.

Anderson, Stephen R. (2012). Languages: A Very Short Introduction. Oxford: Oxford University Press.

Hamalik, Umar. 1983. Metodologi Belajar dan Kesulitan-kesulitan Belajar. Jakarta: Tarsito.

Harriman, P.L. 1980. Handbook of psychological terms. Totowa: Littlefield Adams \& Co.

Irham, M. dan Wiyani, N.A. 2013. Psikologi Pendidikan Teori dan Aplikasi dalam Proses Pembelajaran. Jogjakarta: Ar-Ruzz Media.

Johnson, D. W., Johnson, R., \& Tiffany, M. (1984). Structuring academic conflicts between majority and minority students: Hindrance or help to integration. Contemporary Educational Psychology.

Kirk, A. S \& Gallagher, J. J. 1989. Educating Exceptional Children. Boston: Houghton Mifflin Company.

Tarigan, Henry Guntur. 2015. Membaca Sebagai Suatu Keterampilan Berbahasa. Bandung: Penerbit Angkasa.

Wijaya, Cece. 2010. Pendidikan Remidial. Bandung: PT Remaja Rosdakarya. 